\author{
К. Аратулы $^{1}$ iD , С. Адилгазы ${ }^{2}$ iD , С.С. Алимова ${ }^{3}$ \\ Казахский национальный университет имени аль-Фараби, Казахстан, г. Алматы, e-mail: cri- \\ medep2016@gmail.com,serikhan@mail.ru, saulealimova010@gmail.com

\section{ПОАИГРАФ В АЕЯТЕАЬНОСТИ ПРАВООХРАНИТЕАЬНЫХ ОРГАНОВ}

В данной статье рассматриваются основные проблемы, которые возникают в деятельности правоохранительных органов при использовании полиграфа (Аетектора ^жи). Аоказывается, что опрос с использованием полиграфра представляет собой процедуру оценки субъективной значимости стимула, в связи с чем обосновывается необходимость включения Аанной процедуры в систему методов и средств отечественной судебной психологической экспертизы. На сегодняшний день инструментальный метод психофизиологического выявления скрываемой информации, иными словами обследование с использованием полиграфа (Аетектора ^жи), широко применяется в Республике Казахстан. По данным Общественного объединения «Евразийская ассоциация полиграфологов» только в 2015 году правоохранительные органы и специальные службы Казахстана ввели в строй не менее 75 новых полиграфов самых разных систем и моделей. В Учебном центре Ассоциации за гоА подготовлено 168 специалистов-полиграфологов Аля всех правоохранительных органов.

Стоит отметить тот факт, что использование научно-технических средств способствует быстрому и эффективному раскрытию преступлений, а также уменьшению числа судебных ошибок. В криминалистике и практике оперативно-розыскной деятельности приобретает большое значение использование методов, позаимствованных из других дисциплин. В настоящее время более чем в пятилесяти странах мира (США, Японии, Канаде, Израиле, Турции, Польше, Венгрии и др.) в правоохранительных органах используются методы регистрации психофизиологических реакций ^юдей с целью установления их причастности к преступлениям с помощью полиграфов.

Ключевые слова: полиграф, оперативно-розыскная деятельность, детектор лжи, раскрытие и расследование преступлений, психофизиологический метоА.

\author{
K. Aratuly, S. Adilgazy, S.S. Alimova \\ Al-Farabi Kazakh national university, Kazakhstan, Almaty, \\ e-mail: crimedep2016@gmail.com; serikhan@mail.ru; saulealimova010@gmail.com
}

\title{
Polygraph in law enforcement activities
}

This article discusses the main problems that arise in the activities of law enforcement agencies when using a polygraph (lie detector). It is proved that the survey using a polygraph is a procedure for assessing the subjective исчисляютсяsignificance of the stimulus, and therefore the need to include this procedure in the system of methods and means of domestic forensic psychological examination is justified. To date, the instrumental method of psychophysiological detection of hidden information, in other words, examination using a polygraph (lie detector), is widely used in the Republic of Kazakhstan. According to the public Association «Eurasian Association of polygraph examiners», only in 2015, law enforcement agencies and special services of Kazakhstan put into operation at east 75 new polygraphs of various systems and models. The training center of the Association has trained 168 polygraph specialists for all law enforcement agencies.

It is worth noting that the use of scientific and technical means contributes to the rapid and effective detection of crimes, as well as reducing the number of judicial errors. In criminology and the practice of operational investigative activities, the use of methods borrowed from other disciplines is of great importance. Currently, more than fifty countries around the world (USA, Japan, Canada, Israel, Turkey, Poland, Hungary, etc.) use methods of registering psychophysiological reactions of people in order to establish their involvement in crimes using polygraphs.

Key words: polygraph, operational-search activity, lie detector, disclosure and investigation of crimes, psychophysiological method. 


\author{
Қ. Аратұлы, С. ӘАілғазы, С.С. Алимова \\ Ә^-Фараби атындағы Қазақ, ұлттық университеті, Қазақстан, Алматы қ., \\ e-mail: crimedep2016@gmail.com; serikhan@mail.ru; saulealimova010@gmail.com
}

Құқықққорғау органдарының қызметіндегі полиграф

Бұл мақалада полиграфты (жалғандық детекторы) пайдалану кезінде құқық қорғау органдарының қызметінде туындайтын негізгі проблемалар қарастырылады. Полиграфты пайдалана отырып жүргізілген сауалнама стимулдың субъективті маңыздылығын бағалау рәсімін білдіретіні дәлелденеді, осыған байланысты осы рәсімді отандық сот психологиялық сараптамасының әдістері мен құралдары жүйесіне енгізу қажеттігі негізделеді. Бүгінгі күні жасырылған ақпаратты психофизиологиялық анықтаудың аспаптық әдісі, басқаша айтқанда, пполиграфты (жалғандық, детекторы) пайдалана отырып тексеру Қазақстан Республикасында кеңінен қолданылады. «Еуразиялық, полиграфологтар қауымдастығы» қоғамдық бірлестігінің Аеректері бойынша, 2015 жылы ғана Қазақстанның құқық қорғау органдары мен арнайы қызметтері әртүрлі жүйелер мен модельдердің кемінде 75 жаңа полиграфиясын іске қосты. Қауымдастықтың оқу орталығында бір жыл ішінде барлық құқық қорғау органдары үшін 168 полиграфолог маман даярланды.

Ғы^ыми-техникалық құра^дарды пайдалану қылмыстың тез және тиімді ашылуына, сондайақ сот қателіктерінің санын азайтуға ықпал ететінін атап өткен жөн. Криминалистика мен жеделіздестіру қызметінің тәжірибесінде басқа пәндерден алынған әдістерді қолдану үлкен маңызға ие. Қазіргі уақытта әлемнің елуден астам елінде (АҚШ, Жапония, КанаАа, Израиль, Түркия, Польша, Венгрия және т.б.) құқық қорғау органдарында полиграфтардың көмегімен қылмысқа қатыстылығын анықтау мақсатында адамдардың психо-физиологиялық, реакцияларын тіркеу әдістері пайдаланылады.

Түйін сөздер: полиграф, жедел-іздестіру қызметі, жалғандық, детекторы, қылмыстарды ашу және тергеу, психо-физиологиялық әдіс.

\section{Введение}

Следует отметить тот факт, что Первый Президент Н.А. Назарбаев настоял на широком применении полиграфа в правоохранительной системе, в результате чего 21 мая 2013 г. были приняты поправки в закон «О правоохранительной службе» (Закон Республики Казахстан от 6 января 2011 года № 380-IV «О правоохранительной службе» (с изменениями и дополнениями по состоянию на 29.10.2015 г.), а через год, 19 июня 2014 г. и «Правила прохождения полиграфологического исследования в правоохранительных органах Республики Казахстан» (Постановление Правительства Республики Казахстан от 19 июня 2014 года № 683 «Об утверждении Правил прохождения полиграфологического исследования в знаправоохранительных органах Республики Казахстан»). Сегодня полиграф в правоохранительных органах Казахстана в обязательном порядке применяется в трёх сферах: 1) при приёме на службу в правоохранительные органы; 2) при прохождении очередной аттестации; 3) при осуществлении служебных расследований.

Целью статьи является ознокомление читателя с основными вопросами, возникающими при деятельности правоохранительных органов по использованию полиграфного устройства, так называемого детектора лжи. Кроме того тест (исследование) с использованием полиграфа представляет собой особенный процесс, не относящийся ни к одной отдельно взятой отрасли науки, а комплекс смежных знаний из разных практик медицины, психологии и физики и др., и даже правоведения вместе с информационными технологиями, что в комплексе находит пересечение в криминалистической и судебно-экспертной науке и практике.

\section{Материалы и методы}

Стоит отметить тот факт, что использование научно-технических средств способствует быстрому и эффективному раскрытию уголовных правонарушений, вместе с тем уменьшая и сокращая число судебных ошибок и погрешностей. В криминалистике и практике ОРД приобретает большое значение использование методов, позаимствованных из других отраслей науки и дисциплин. В целях исследования проблемы изучены и проанализированы научные источники, опыт и законодательства таких зарубежных стран как США, Канада, Россия и ряда Европейских государств. При проведении анализа правовых, медицинских и пробационных (практических) аспектов данного научно-исследоватльского вопроса были применены следующие методы: анализ и синтез, историко-практический метод, 
формализации, сравнительно-аналитический метод, логические методы, валидация и верификация, психоанализ, тактико-поведенческие, судебно-криминалистические методы, общенаучные, наблюдение и др.

\section{Результаты и обсуждение}

Современная борьба с преступностью характеризуется ростом опасных криминальных проявлений, но особенно их организованные формы. Увеличение числа тяжких латентных преступлений, объединение преступников в организованные группы и сообщества, повышение уровня их вооруженности и технической оснащенности, сращивание с коррумпированными должностными лицами объективно требуют адекватных мер со стороны правоохранительных органов.

Всоздавшихсяусловияхправоохранительные и иные государственные органы вынуждены активно внедрять в отечественную практику борьбы с опасными проявлениями преступности, стабилизации оперативной обстановки в целом новые, эффективные средства, методы, формы их выявления и раскрытия. Одним из приоритетных направлений в этом вопросе стало комплексное использование достижений прикладной психологии в сочетании с техническими устройствами.

Полиграф-этомногоцелевойприбор, который предназначен для одновременной регистрации дыхания, кровяного давления, биотоков (мозга, сердца, скелетной и гладкой мускулатуры и т.п.) и других физиологических процессов. Так же применяется в клинической медицине, медико-биологических и психологических исследованиях. Специализированный полиграф - это полиграф, который предназначен для целей выявления возможно скрываемой человеком информации путем контроля его физиологических реакций в ответ на задаваемые вопросы (далее под полиграфом подразумевается именно специализированный полиграф). Приборы этого класса в силу своих конструктивных особенностей не используют в медицинской (клинической) практике и эпизодически применяют в психологии или психиатрии в исследовательских целях. Опрос с использованием полиграфа (ОИП) - частная форма опроса, осуществляемая исключительно с добровольного согласия опрашиваемого плица, с применением безвредных для здоровья технических средств, направленная на выяв- ление у человека возможно скрываемой им информации.

В настоящее время имеет место тенденция увеличения практики применения опросов с использованием полиграфа в ведущих странах мира: США, Франции, Италии, Германии. Военная разведка, полиция, министерство обороны, ФБР, ЦРУ применяют эту методику, так же как и промышленные компании, банки, торговые фирмы. По данным Американскойк ассоциации операторов полиграфа, в настоящее время полиграф используют более 60 государств.

За последние годы в Республике Казахстан разработана система применения полиграфа применительно к оперативно-розыскной деятельности: создана нормативная база, разработаны квалификационные требования к специалистам, проводящим опросы, методика их подготовки, отработаны приемы проведения опроса и подготовлены рекомендации по его проведению (Алесковский 2014: 50). Вместе с тем использование полиграфа по-прежнему остается научной, нравственной и практической проблемой.

Одним из аспектов «проблемы полиграфа» является отождествление понятий «полиграф» и «детектор лжи». Для того чтобы разобраться в данном вопросе, необходимо обратиться к принципу работы полиграфа.

Полиграф регистрирует изменения физиологических параметров человека, которые практически не поддаются контролю со стороны сознания и, следовательно, являются объективными показателями функционирования организма и его систем. Физиологические реакции человека могут изменяться при предъявлении ему значимых (т.е. важных для него) стимулов. В качестве стимулов используются слова, фотографии, рисунки, предметы и т.д. Так, самый распространенный демонстрационный тест с использованием полиграфа заключается в «отгадывании» имени тестируемого. Собственное имя (фамилия) является значимым для любого человека, поэтому при предъявлении данного стимулам физиологические реакции испытуемого будут отличаться от фоновых (полученных при предъявлении испытуемому различных «чужих» имен). Полиграф же способен зарегистрировать эти отличия.

Первым из отечественных психологов сформулировал генеральный принцип психофизиологических методов детекции лжи А.Р. Лурия: «Единственная возможность изучить механику внутренних «скрытых» процессов сводится к 
тому, чтобы соединить эти скрытые процессы с каким-нибудь одновременно протекающим рядом доступных для непосредственного наблюдения процессов... в которых внутренние закономерности и соотношения находили бы свое отражение» (Лурия 1984: 329).

Примеры показывают, что действительно, если мы встревожены, обеспокоены, возбуждены, испытываем страх, у нас появляется эмоциональное напряжение. Оно проявляется в различного рода физиологических показателях: учащается или снижается частота пульса, изменяются ритм дыхания, статическая проводимость кожи, температура тела, характер биотоков мозга, т.е. организм реагирует на возникшие затруднения, старясь выйти из создавшегося положения, занимая состояние повышенной мобилизованности. Можно зафиксировать такую эмоциональную реакцию человека, сопровождающуюся физиологическими изменениями, которые возникают ввиду создавшихся трудностей. Эмоции - это непосредственная реакция человека на внешнее или внутренне воздействие, выражающая его готовность действовать определенным образом. Эмоции находят проявление в показателях, и, что характерно, эти показатели проявляются непроизвольно, против воли и желания человека. Конечно, кое-какие реакции человек может регулировать физиологически, но далеко не все, а тем более в состоянии напряжения, интеллектуального поиска (как правильно сказать, как правильно среагировать, как правильно держаться). Многое упускается из вида, а вот полиграф фиксирует реакции объективно.

Проверка на полиграфе состоит в том, что оператор, проводящий обследование, задает тестируемому человеку вопросы, требующие однозначного ответа. Одновременно прибор регистрирует изменения физиологических процессов в организме проверяемого, возникающих как реакция организма на моделируемую ситуацию. Эти реакции - материальное отражение эмоций и переживаний человека. Эмоциональные переживания вызываются страхом быть разоблаченным, опасениями потерпеть поражение или впасть в немилость, быть опозоренным в глазах коллег, знакомых или волнением, что прибор что-нибудь не так покажет.

Если обследуемый не чувствует себя виновным, он обычно старается сотрудничать с экзаменатором и испытывает скорее не страх перед «детектором» лжи, а обычное волнение, которое вскоре проходит или заметно ослабевает. Поэтому у невиновных людей, как правило, отклонений физиологических параметров намного меньше, чем у виновных. Существуют специальные методики дифференциации реакций обычного волнения и страха разоблачения. Конечно, и у невиновных испытуемых возникают опасения, связанные с прохождением обследования на детекторе. Однако оператор обязательно предварительно объяснит работу детектора лжи, обсудит с проверяемым сотрудником вопросы, которые ему будут задаваться во время проверки, это значительно уменьшит напряжение.

Вопросы, задаваемые при полиграфной проверке, активизируютсимпатическуюнервную системуивызываютфизиологическиеизменения, которые могут быть зарегистрированы, измерены и проанализированы. Полиграф - это совокупность нескольких усилителей низкой частоты, которые позволяют зафиксировать определенные физиологические параметры, такие как амплитуда дыхания, пульс, давление крови, электрическая активность кожи, частота мигания, а также ритмы головного мозга и сердца. Чем больше показаний, тем достовернее результаты теста. Успех в большей мере зависит от опыта оператора, поскольку объективных показателей лжи не существует. Ему необходимо суметь связать физиологические параметры - неритмичное дыхание, учащение сердечного ритма, подъем давления крови - с психологическими и, что самое главное, правильно интерпретировать их.

Опираясь на работы А.Р. Лурия, Ю.И. Холодный, один из авторитетных ученых в данной области, полиграфолог с тридцатилетним стажем работы, первым обозначил явление, которое лежит в основе процедуры проверки на полиграфе. Это явление было сформулировано им как психофизиологический феномен.

Психофизиологический феномен заключается в том, что внешний стимул (слово или предмет, фотография), несущий человеку значимую в конкретной ситуации информацию о событии, запечатлённом в его памяти, устойчиво вызывает физиологическую реакцию, превышающую реакции на родственные (однородные) стимулы, предъявляемые в тех же условиях, но не связанные с упомянутым событием и не несущие человеку ситуационно значимой информации (Алесковский 2015: 23).

Сам полиграф как прибор $\mathrm{H}^{\mathrm{y}}$ икакую ложь или правду выявить не способен, поскольку ложь - 
это феномен человеческого общения. Вывод об искренности или неискренности испытуемого делает полиграфолог, сравнивая показатели физиологических реакций испытуемого, полученные с помощью полиграфа в ходе специально организованного опроса.

Таким образом, полиграф не является «детектором лжи», а представляет собой прибор, предназначенный для исследования субъективной значимости предъявляемых стимулов.

Другая проблема использования полиграфа в правоприменительной практике - это проблема вероятностного характера результатов ОИП.

В мировой практике опросыс использованием полиграфа применяют для решения задач звух классов.

Во-первых, проверки при различного рода расследованиях или разбирательствах (уголовных, служебных и т.д.), когда опрашиваемый подвергается проверке на предмет сокрытия информации, представляющей интерес для проводимого дознания. При всем разнообразии расследований в их основе всегда лежит какоето конкретное событие (кража, подлог и т.д.), и полиграфолог определяет причастность конкретных лиц к этому событию, их осведомленность о деталях, обстоятельствах или признаках расследуемого события.

Во-вторых, скрининговые (англ. screen просеивать, проверять на благонадежность) проверки при отборе кадров, оценке персонала и своевременного выявления его возможной нелояльности. Рентабельность применения проверок на полиграфе при приеме на работу определяется следующими факторами: быстротой получения точной информации о респонденте; склонностью людей быть более правдивыми и откровенными во время проверок на полиграфе, чем при иных кадровых опросах; высокой точностью и эффективностью метода полиграфной проверки.

Выполнение ОИП (опросов с использованием полиграфа) в интересах отбора кадров способствует своевременному выявлению нежелательных (с точки зрения работодателя) наклонностей у нанимаемого на работу лица или скрываемых этим лицом фактов биографии. Выпонение ОИП в интересах проверки работающего персонала или иных лиц способствует выявлению фактов нарушения установленных работодателем норм поведения или деяний, наносящих ущерб законным интересам работодателя. Проверка на полиграфе при проведении расследований по различным происшествиям (кража, подлог, подделка документов, разглашение коммерческой тайны и др.) позволяет:

- оправдать лиц, не виновных в происшествии и не имеющих к нему никакого отношения;

- установить круг лиц, причастных к происшествию и определить вид долевого и ролевого участия в происшествии каждого конкретного подозреваемого;

- установить местонахождение похищенного имущества;

- в некоторых случаях - склонить виновного человека к даче признательных показаний.

Опрос с использованием полиграфа при проведении кадровых (скрининговых) проверок позволяет:

- оперативно (в течение 2-3 часов) проверить достоверность анкетных данных человека, поступающего на работу;

- выявить у кандидата на работу наличие алкогольной зависимости;

- выявить у кандидата на работу наличие наркотической зависимости;

- выявить у кандидата на работу наличие хронических заболеваний и травм;

- выявить у кандидата на работу наличие незарегистрированного оружия;

- выявить у кандидата на работу наличиеи фактов привлечения к уголовной ответственности;

- выявить у кандидата на работу наличие эпизодов мошенничества, краж, подлогов и т.д. на предыдущих местах работы;

- выявить у кандидата на работу наличие связей с криминальными структурами;

- выявить лиц, которые устраиваются на работу по заданию криминальных структур;

- выявить, кто из сотрудников передает не подлежащую разглашению информацию;

- определить степень лояльности работающего персонала.

Серьезной проблемой использования полиграфа в правоприменительной практике является проблема соблюдения методических принципов проведения ОИП.

К основным правилам ОИП относятся: принцип добровольности (опрашиваемый должен выразить добровольное согласие на проведение опроса); наличие предварительной беседы (с целью подготовить опрашиваемого к процедуpe опроса); ознакомление опрашиваемого с содержанием вопросов (чтобы исключить различное понимание смысла вопросов и их новизну); одновременная регистрация как минимум трех 
физиологических показателей: дыхания, сердечно-сосудистой деятельности и кожно-гальванической реакции; многократное (не менее трех раз) повторение задаваемых вопросов с целью исключения случайных реакций; правильная организация условий проведения ОИП: отсутствие побочных раздражителей, «лишних людей» в помещении, шума и т.д.

Проведенный автором анализ деятельности ряда специалистов-полиграфологов показывает, что, к сожалению, зачастую ими при проведении ОИП нарушаются основные правила данного метода, что приводит к резкому снижению результативности опроса и делает выводы недостоверными.

Эффективность проведения опросов с использованием полиграфа напрямую зависит от опыта и качества подготовки специалиста-полиграфолога. Вопрос о профессиональной подготовке специалистов по опросам с использованием полиграфа, при всей кажущейся его обособленности, в сущности, является едва ли не центральным среди комплекса других вопросов, охватывающих теоретические и прикладные аспекты этого метода.

Работа полиграфолога - это самостоятельный вид деятельности, требующий глубоких знаний в области теории и практики применения метода ОИП. Отечественный опыт и данные зарубежных стран показывают, что подготовка полиграфолога - процесс длительный. Овладеть специальностью полиграфолога самостоятельно, без помощи наставника, только лишь упражняясь с «детектором лжи» в лабораторных условиях, принципиально невозможно.

Обучение методу и прикладным приёмам выполнения ОИП за рубежом осуществляется почти индивидуально (в группах по два-три человека) и предполагает обязательную стажировку в реальных условиях под контролем опытного полиграфолога-профессионала. Поэтому становится понятным устоявшееся среди полиграфологов мнение о том, что успех ОИП в реальных условиях на $90 \%$ зависит от специалиста.

С 1 июля 2008 года заработало первое в истории Казахстана общественное объединение специалистов-полиграфологов - «Алматинская ассоциация полиграфологов» (Гинзбург 2011: 25). Процесс внедрения и использования полиграфа ускорился многократно и сегодня его уже вряд ли можно остановить. Алматинская ассоциация полиграфологов со временем приняла в свои ряды полиграфологов практически из всех крупных городов Казахстана, а также России,
Беларуси, Кыргызстана, Азербайджана, Монголии и других стран и в 2012 году логично была переименована в «Евразийскую ассоциацию полиграфологов». Отечественные полиграфологи окрепли, приобрели большой практический опыт и международное признание. В августе 2015 года большая группа полиграфологов из числа членов Общественного объединения «Евразийская ассоциация полиграфологов» была приглашена для участия в юбилейной пятидесятой конференции AРA - American Polygraph Association (Американской ассоциации полиграфологов), которая проходила в г. Чикаго (Иллинойс, США). В течение шести дней, совместно с ведущими полиграфологами планеты, рассматривали злободневные вопросы мировой полиграфологии, перспективные методики обследований, особенности расследования особо тяжких преступлений с применением полиграфа, возможности выявления изощренных видов противодействия полиграфной проверке и т.д.

Лидером по проведению исследований с использованием полиграфа остаются США. Ежегодно в данной стране проводится более миллиона проверок на полиграфе, то есть больше, чем во всех остальных странах вместе взятых. Однако, различие законов на уровне штатов весьма существенно: в одних возможность применения полиграфа полностью исключается, в других результаты исследований, полученных с помощью полиграфа, могут использоваться в суде в качестве доказательств. Например, в штатах Калифорния, Техас, Пенсельвания.

После многих лет применения полиграфа в различных областях в США в 1988 году был принят «Закон о защите служащих от полиграфа», который жестко определил методику проведения подобных исследований как в государственной, так и в коммерческой сферах.

В США, приступая к проверке на полиграфе, участника этой процедуры просят дать добровольное письменное согласие в установленной форме, одновременно информируя его:

- о праве молчать, поскольку любое заявление может быть использовано против него в суде;

- о праве участника в любой момент остановить ход исследования;

- о праве адвоката присутствовать во время проверки на полиграфе;

- о праве воспользоваться помощью адвоката на любом этапе испытания на полиграфе (Холодный 2000: 55).

На сегодняшний день психофизиологиче- 
ское исследование широко применяется в целях профилактики и предупреждения преступлений при приеме на службу, а также в ходе оперативной деятельности правоохранительных органов США. Тем не менее, несмотря на положительные результаты проведенных исследований, американскими учеными так и не выработаны единые естественнонаучные основы психофизиологического метода «детектора лжи».

Сложный комплекс тесно связанных нейрои психофизиологических процессов в организме человека, действующих как единое целое при проведении исследования с использованием полиграфа, остается в значительной степени еще неизученным. Результаты диагностики с использованием полиграфа носят вероятностный характер, а результат исследования основан на субъективной оценке специалиста-полиграфолога.

Нужно отметить, что методика инструментальной диагностики на полиграфе ипользуется не только в плане обеспечения деятельности по сбору информации обвинительного характера в процессе разработки следственных версий, но и в целях повышения эффективности защиты прав и законных интересов подозреваемого. По оценке американских операторов полиграфа, вера в эффективность полиграфа в ходе расследований настолько велика, что сторона защиты часто инициирует проведение этой процедуры, чтобы снять необоснованные обвинения.

По данным Министерства обороны США, проверки в оправдательных целях составляют более $15 \%$ от общего числа испытаний на полиграфе и ежегодно исчисляются тысячами.

Второй страной после США по количеству проверок, проводимых на полиграфе, является Канада. Этот метод активно используется в ходе расследования преступлений, реже при кадровых проверках в органах исполнительной власти и в коммерческих целях (www.poligraf.sp.ru).

Однако, в отличие от США, на территории Канады результаты полиграфных проверок не используются в судах для доказательства вины подсудимого.

Канадские правоохранительные органы прибегают к исследованиям с помощью полиграфа в целях установления самого факта совершения преступления, сужения круга подозреваемых, получения дополнительной информации. Полиграфные проверки проводятся не только в отношении обвиняемого, но и в отношении потерпевшего, свидетелей, истцов.

На третьем месте в мире по числу высококвалифицированных кадров, проводящих иссле- дования с использованием полиграфа, остается Япония, где полиграф применяется с 1956 года. Ведущим пользователем этого метода в стране является полиция. Уже на протяжении 50 лет японские исследователи занимаются вопросами теории и практики применения полиграфа. С 1959 года результаты проверок на полиграфе принимаются в качестве доказательств в судах низшей инстанции, а к началу 70 -х годов стали приниматься и Верховным Судом, но по усмотрению судьи.

Европейским странам присуща совершенно иная картина использования данного метода.

В Великобритании попытка внедрения метода психофизиологического исследования не увенчалась успехом. Решение правительства Маргарет Тэтчер о необходимости проведения систематических обязательных проверок на полиграфе сотрудников спецслужб вызвало большую волну протеста, и проект был приостановлен на неопределенный срок.

В начале XX века в Германии полиграф активно использовался для расследования преступлений. Однако в 1954 году было принято судебное решение со ссылкой на Конституцию ФРГ, запрещающее применение полиграфа в ходе уголовного судопроизводства. Данная позиция была обоснована тем, что проверка на «детекторе лжи» унижает достоинство человека, его неприкосновенность.

18 августа 1981 года Конституционный суд ФРГ подтвердил запрет на использование полиграфа на территории ФРГ даже при согласии испытуемого.

Уголовно-процессуальный кодекс Австрии также запрещает использование полиграфа при расследовании преступлений, даже если сам обвиняемый будет ходатайствовать об этом (www. detectivecobra.ru).

Известны некоторые единичные случаи признания судом Польши результатов исследования с применением полиграфа в качестве доказательств по уголовному делу. Однако, на сегодняшний день этот метод используется в рамках оперативно-разыскной деятельности и при построении следственных версий в качестве ориентирующей информации.

Аналогичной позиции на сегодняшний день придерживаются Австралия, Боливия, Венгрия, Гайана, Гватемала, Индонезия, Иордания, Испания, Италия, Кения, КНР, Колумбия, Кувейт, Марокко, Молдова, Румыния, Словения, Нигерия, Пакистан, Панама, Франция, Ямайка и другие страны. 
Говоря о возможностях использования полиграфа в различных странах, следует заметить, что в основном подготовку для работы с полиграфом специалисты из разных стран проходили в США. Что касается Казахстана, в последние годы широкое распространение по использованию полиграфа получила не только сфера по противодействию преступности, но и частная сфера.

Существуют в практике примеры признания результатов полиграфического исследования судом в качестве допустимых доказательств. Так, в ходе судебного разбирательства судьей Дзержинского городского суда Нижегородской области С. было назначено проведение психофизиологического исследования с применением полиграфного аппарата. Данное исследование проводилось с добровольного согласия самого подсудимого в присутствии педагога (поскольку подсудимый был несовершеннолетним) и адвоката, с согласия всех участников процесса. Заключению эксперта-полиграфолога судья дала оценку в приговоре и пришла к выводам о виновности лица, в том числе опираясь на выводы психофизиологического исследования (Ушаков 2015: 185).

Столь разная практика применения результатов, полученных с использованием полигра$\phi а$, во многом обусловлена отсутствием единой правовой основы его применения в данной стране. Тем не менее, неоспорима значимость проведения психофизиологических исследований с использованием полиграфа, особенно на стадии предварительного расследования для получения, главным образом, ориентирующей информации. В следственной практике имеется немало примеров, когда сам факт проведения исследования с использованием полиграфа и предъявления результатов проверки оказывал на опрашиваемых лиц эффективное психологическое воздействие и побуждал их к добровольной даче признательных показаний.

В настоящее время деятельность по применению полиграфных устройств в уголовном судопроизводстве России является относительно новой и малоизученной, о чем свидетельствуют многочисленные публикации и исследования, проводимые юридической общественностью по данному направлению. Причины такой обеспокоенности юридической польшиобщественности вопросами применения полиграфных устройств в уголовном судопроизводстве вполне понятны: для практических работников это возможность иметь в своем арсенале передовое средство противодействия преступным проявлениям, для других вечные вопросы по соблюдению прав и законных интересов участвующих в уголовном процессе России (Ушаков 2014: 71).

Большинство психологов сходятся во мнении, что мало доказательств того, что тесты на детекторе лжи могут точно обнаружить ложь. Но, как утверждает психолог Леонард Сакс, доктор философии, идея о том, что мы можем обнаружить правдивость человека, отслеживая психофизиологические изменения, является скорее мифом, чем реальностью. Даже термин «детектор лжи», используемый для обозначения проверки на детекторе лжи, является неправильным. Так называемое «обнаружение лжи» включает в себя вывод обмана путем анализа физиологических ответов на структурированный, но нестандартный ряд вопросов (Saxe 1991: 409-15).

Инструмент, обычно используемый для проведения полиграфических тестов, состоит из физиологического регистратора, который оценивает три показателя вегетативного возбуждения: частоту сердечных сокращений/кровяное давление, дыхание и проводимость кожи. Большинство экспертов сегодня используют компьютеризированные системы записи. Частота и глубина дыхания измеряются с помощью пневмографов, обернутых вокруг груди субъекта. Сердечно-сосудистая активность оценивается с помощью манжета для измерения артериального давления. Кожная проводимость, называемая гальванической кожей или электродермальным откликом, измеряется с помощью электродов, прикрепленных к кончикам пальцев пациента.

Записывающий инструмент и методы опроса используются только во время проверки на полиграфе. Типичный экзамен включает в себя предтестовую фазу, во время которой объясняется методика и рассматривается каждый тестовый вопрос. Предтестовое интервью предназначено для того, чтобы субъекты понимали вопросы и вызывали их беспокойство по поводу обмана. Проверки на полиграфе часто включают процедуру, так называемую «тест на стимуляцию», которая демонстрирует точность инструмента в обнаружении обмана.

Например, проверка подозреваемого в краже может включать такие вопросы, как «были ли украдены 5000, 10000 либо 20000 теңге»? Если только подозреваемый знает правильный ответ, большая физиологическая реакция на правильный выбор будет указывать на обман. При наличии достаточного количества предметов может быть разработана психометрически обоснован- 
ная оценка. Одним из ограничений GKT детектора является то, что он может использоваться только тогда, когда следователи располагают информацией, которую мог знать только виновный субъект. Интерпретация «без обмана» также является потенциальным ограничением.

Точность тестирования на полиграфе является теоретической: нет никаких доказательств того, что какой-либо характер физиологических реакций является уникальным для обмана. Честный человек может нервничать, отвечая правдиво, а нечестный человек может не беспокоиться. Кроме того, есть несколько исследований, которые подтверждают способность полиграфических процедур обнаруживать обман. Как отмечают доктор Сакс и израильский психолог Гершон Бен-Шахар, «на самом деле невозможно провести надлежащее исследование достоверности». В реальных ситуациях очень трудно понять, что такое истина (Saxe \& Ben-Shakhar 1999: 203-23). Особая проблема заключается в том, что исследования на полиграфе не отделяют подобные эффекты от фактической связи между обманом и его физиологическими реакциями. Одна из причин, по которой тесты на полиграфе могут показаться точными, заключается в том, что субъекты, которые считают, что тест работает и что их можно обнаружить, могут признаться или будут очень взволнованы при опросе. Если эта точка зрения верна, детектор лжи лучше назвать детектором страха.

Несмотря на отсутствие исследований, подтверждающих тесты на детекторе лжи, продолжаются усилия по разработке и оценке новых подходов. Некоторая работа предполагает использование дополнительных вегетативных физиологических показателей, таких как сердечный выброс и температура кожи. Такие меры, однако, более специфичны для обмана, чем тесты на детекторе лжи. Другие исследователи, такие как Фрэнк Эндрю Козел, доктор медицины, исследовали функциональную визуализацию мозга как меру обмана. Исследовательская группа доктора Козел обнаружила, что ложь, по сравнению с правдой, активируется в пяти областях мозга (Kozel 2004: 852-56). Однако результаты в настоящее время не поддерживают данное использование для обнаружения обмана в реальных индивидуальных случаях.

Проверка на полиграфе вызвала значительный научный и общественный спор. Большинство психологов и ученых согласны с тем, что оснований для достоверности проверок на детекторе лжи мало. Суды, в том числе Верховный суд США, неоднократно отклоняли использование полиграфических доказательств из-за присущей им ненадежности. Тем не менее, проверка на детекторе лжи по-прежнему используется в несудебных ситуациях, часто для проверки персонала, но иногда для оценки правдивости и чистоплатности подозреваемых и свидетелей, а также для отслеживания преступников на испытательном сроке. Тесты на детекторе лжи также иногда используются лицами, стремящимися убедить других в своей правоте и невиновности и в узком диапазоне обстоятельств, частными агентствами и корпорациями (Lykken 1998: 2d ed.).

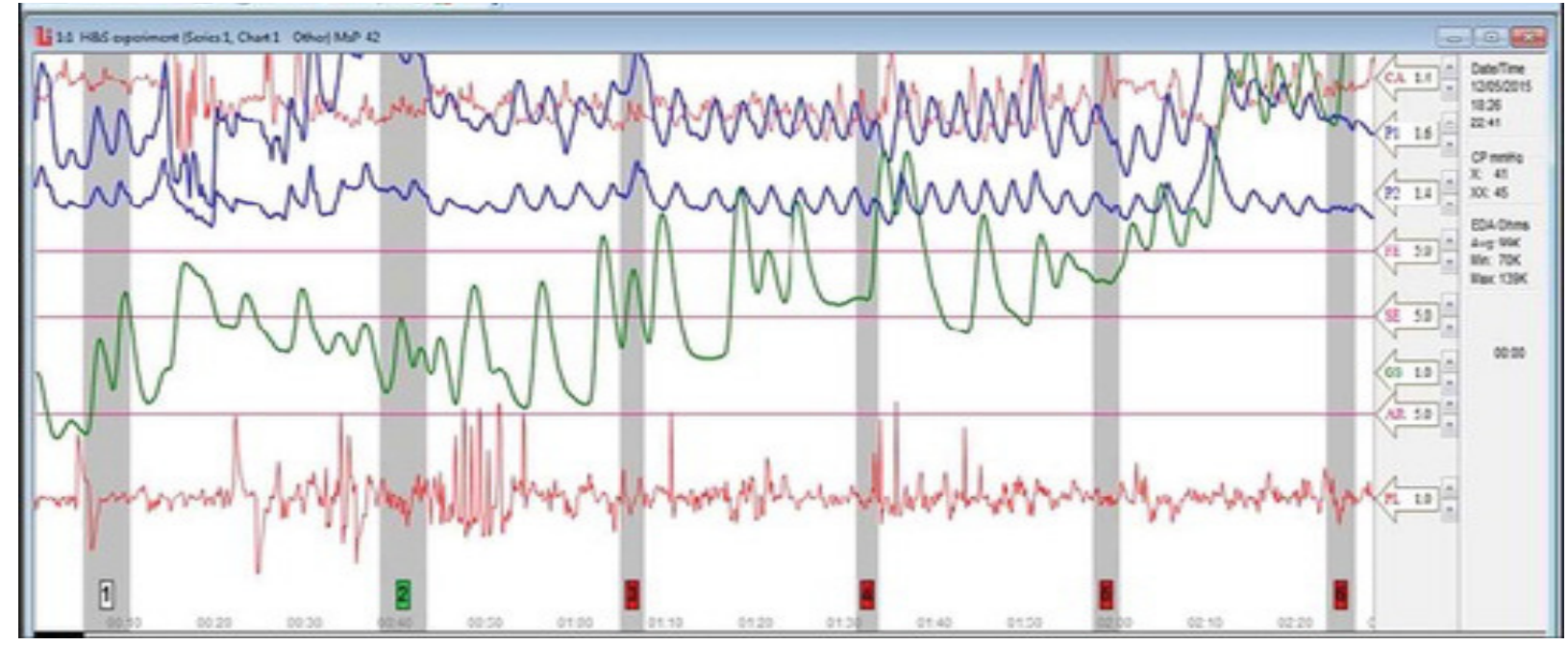

Рисунок 1 - Цифровой прикрепленных полиграфический работу вывод 
Современные полиграфы больше не используют ручки, прикрепленные к тамбурам, чтобы писать чернилами на рулоне бумаги, управляемом часовым механизмом Mackenzie так, как работали оригинальные модели полиграфа Keeler. Современные полиграфы производят цифровые выходы, которые поступают непосредственно из измерительных приборов в компьютер с соответствующим программным обеспечением для полиграфа (Рисунок 1).

Физиологические каналы, которые измеряет полиграф, в основном не изменились по сравнению с оригинальными моделями Килера (Buckley 1980: 1187-1207). Это сердечно-сосудистая активность (красная линия, рисунок 1), дыхательная активность (синяя линия, рисунок 1) и электродермальная активность (зеленая линия, рисунок 1). Чувствительные к давлению рецепторы, барорецепторы, играют центральную роль в активации соответствующей системы, когда кровяное давление внезапно падает или повышается, поддерживая тем самым базальное кровяное давление, необходимое для устойчивой жизни (Сacioppo 1994: 586-598).

\section{Заключение}

В заключение обозначим возможные направления использования полиграфа в правоприменительной деятельности, помимо расследования преступлений и отбора персонала:

- организация мониторинга по принципу обратной связи при обучении персонала правоохранительных органов навыкам психологической саморегуляции;

- исследования механизмов субсенсорного восприятия, селекции информации, корреляции значимости сигнала и личностного смысла;

- клиническая экспертиза наличия у сотрудника правоохранительных органов посттравматического стрессового расстройства (для установление группы инвалидности т.д.);

- психолого-физиологическая диагностика агрессивности и тревожности личности;

- установление идентификационных социальнодемографических характеристик личности лиц, страдающих частичной или полной амнезией.

\section{Литература}

Алесковский С.Ю. Полиграф в Казахстане - 15 лет поступательного развития // «Первые итоги и основные направления использования полиграфа в Казахстане»: Материалы международной научно-практической конференция. - Алматы: Академия экономики и права, 2014. - С. 50.

Алесковский С.Ю. Становление и развитие полиграфа в Казахстане // Эксперт-Криминалист: Федеральный научнопрактический журнал. - М., 2015. - № 4. - С. 23.

Гинзбург А.Я. Проблемы применения полиграфа в судопроизводстве Казахстана и других сферах деятельности // Актуальные проблемы и перспективы использования полиграфа: Материалы Круглого стола, посвященные 75-летию д.ю.н, профессора А.Ф. Аубакирова. - Алматы: Академия экономики и права, 2011. - С. 25.

Лурия А.Р. Диагностика следов аффекта // Психология эмоций: Тексты. - М.: Изд-во МГУ, 1984. - С. 329.

Ушаков А.Ю., Андриянова О.Ю. Использование результатов психофизиологических исследований с помощью полиграфа в раскрытии и расследовании уголовных дел: монография. - Н. Новгород, 2014. - С. 71.

Ушаков А.Ю., Беркович О.Е. Вестник Нижегородской академии МВД России / Архив Дзержинского городского суда Нижегородской области. д. № 1-88/10. - Н, 2015. - С.185.

Холодный Ю.И. Применение полиграфа при профилактике, раскрытии и расследовании преступлений. - М.: Мир безопасности, 2000. - С. 55.

URL: htpp://www.poligraf.sp.ru/metric.html

URL: htpp://www.detectivecobra.ru/oligraf-in- world

Buckley J.P. (1980) Polygraph technology. Forensic Psychiatry (pp. 1187-1207).

Cacioppo J.T., Berntson G.G., Binkley P.F., Quigley K.S., Uchino B.N. \& Fieldstone A. (1994) Autonomic cardiac control. II. Noninvasive indices and basal response as revealed by autonomic blockades. Psychophysiology, vol. 31, no 6, pp. 586-598.

Kozel F.A., Padgett T.M. \& George M.S. (2004) A Replication Study of the Neural Correlates of Deception. Behavioral Neuroscience, vol. 118, no 4, pp. 852-56.

Lykken D. (1998) Tremor v krovi: ispolzovanie I zloupotreblenie detektorom lzhi [A Tremor in the Blood: Uses and Abuses of the Lie Detector]. New York: Perseus, 2d ed.

Saxe L. (1991) Lozh: mysli prikladnogo socialnogo psikhologa [Lying: Thoughts of an applied social psychologist]. American Psychologist, vol. 46, no 4, pp. 409-15.

Saxe L. \& Ben-Shakhar G. (1999) Admissibility of polygraph tests: The application of scientific standards post-Daubert. Psychology, Public Policy and the Law, vol. 5, no 1, pp. 203-23. 


\section{References}

Aleskovskii S.Yu. (2014) Polygraph v Kazakhstane - 15 let postupatelnogo razvitya/ «Pervie itogi i osnovnie napravlenya ispolzovanya polygrapha v Kazakhstane» [Polygraph in Kazakhstan - 15 years of progressive development/ First results and main directions of polygraph use in Kazakhstan»] Materials of the international voluntary scientific and practical banning conference. Almaty: Academy of Economics and measured rights, 2014. p.50.

Aleskovskii S.Yu. (2015) Stanovlenie i razvitie polygrapha v Kazakhstane/ Expert-Criminalist: Federal scientific and practical magazine [Formation and development of polygraph in Kazakhstan/ Forensic Expert]. M., no 4, p. 23.

Ginzburg A.Ya. (2011) Problemy primenenya polygrapha v sudoproizvodstve Kazakhstana i drugih spherah deyatel'nosti [Problems of using a polygraph in Kazakhstan's legal proceedings and other areas of activity] / Current research problems and exculpatory prospects abstract of the use of other polygraph: Materials for a round table discussion dedicated to the 75th anniversary of the Doctor of Law and Professor A.F. Aubakirov. Almaty: Academy of Economics and rights. p. 25.

Lurya A.R. (1984) Diagnostika sledov affecta//Psihologia emocii: Texts [Diagnostics of traces of affect// psychology of emotions: Texts] M.: MGU, p. 329.

Ushakov A.U., Andriyanova O.Yu. (2014) Ispol'zovanie rezuktatov psihophiziologicheskih issledovanii s pomoshiyu polygrapha $\mathrm{v}$ raskritii i rassledovanii ugolovnih del: monographya [Using the results of the analysis of psychophysiological guilt studies with the special help of a human polygraph in the analysis of disclosure and experience in the investigation of criminal cases: monograph]. N. Novgorod, p. 71.

Ushakov A.U., Berkovich O.E. (2015) Vestnik Nizhegorodskoi akademii MVD Rossii / Arhiv Dzerzhinskogo gorodskogo suda Nizhegorodskoi oblasti [Archive of the Dzerzhinsky city enforcement court in the Nizhny Novgorod region] D. no 1-88/10, p. 185.

Holodnyi Yu.I. (2000) Primenenie polygrapha pri profilaktike, raskritii i rassledovanii prestuplenii. [The use of the polygraph by the author is recognizable in the process of its prevention, detection and investigation of crimes]. M.: Mir bezopasnosti, 2000 . p.55.

URL: htpp://www.poligraf.sp.ru/metric.html

URL: htpp://www.detectivecobra.ru/oligraf-in- world

Buckley J. P. (1980): Tekhnologiya poligraphii [Polygraph technology]. Forensic Psychiatry (pp. 1187-1207).

Cacioppo J.T., Berntson G.G., Binkley P.F., Quigley K.S., Uchino B.N. \& Fieldstone A. (1994) Avtonomnyi control serdca. II Neinvazivnye pokazateli i bazalnye otvety, vyyavlennye vegetativnymi blokadami [Autonomic cardiac control. II. Noninvasive indices and basal response as revealed by autonomic blockades]. Psychophysiology, vol. 31, no 6, pp. 586-598.

Kozel F.A., Padgett T.M. \& George M.S. (2004) Replikacionnoe issledovanie neyronnyh korrelyatov obmana [A Replication Study of the Neural Correlates of Deception]. Behavioral Neuroscience, vol. 118, no 4, pp. 852-56.

Lykken D. (1998) Tremor v krovi: ispolzovanie i zloupotreblenie detektorom lzhi [Tremor in the Blood: Uses and Abuses of the Lie Detector]. New York: Perseus, $2 \mathrm{~d}$ ed.

Saxe L. (1991) Lozh: mysli prikladnogo socialnogo psikhologa [Lying: Thoughts of an applied social psychologist]. American Psychologist, vol. 46, no 4, pp. 409-15.

Saxe L. \& Ben-Shakhar G. (1999) Dopustimost testov na poligraphe: primenenie nauchnyh standartov posle Dauberta [Admissibility of polygraph tests: The application of scientific standards post-Daubert]. Psychology, Public Policy and the Law, vol. 5, no 1, pp. 203-23. 